Journal Plus Education, ISSN: 1842-077X, E-ISSN (online) 2068-1151 Vol XIX (2018), No. 1. pp. 55-65

\title{
PRESCHOOL INSTITUTION AS A DETERMINANT OF THE DEVELOPMENT OF PETTY MOTORISM IN PRE- SCHOOL CHILDREN
}

\author{
Danica DŽINOVIĆ, PhD \\ danica.dzinovic@uf.bg.ac.rs \\ Dragan MARTINOVIĆ, PhD \\ dragan.martinovic@uf.bg.ac.rs \\ Danimir MANDIĆ, PhD \\ danimir.mandic@uf.bg.ac.rs; dekan@uf.bg.ac.rs \\ Veljko BANĐUR, PhD \\ veljko.bandjur@uf.bg.ac.rs \\ Teacher Education Faculty, University of Belgrade
}

Abstract: The paper first examined the complexity of the preschool institution and assessed the status of petty motoring for children entering the first grade of the Elementary School, and the nestablished the relationship between the indicators of petty motor is mof children on the one hand and the length of attendance at the preschool institution from one, two, three and many years on the other. The aim of the research is to determine whether and how much attendance of a preschool institution affects the development of graphomotor readiness and visual perception in children going to school. In other words, this research was supposed to find out whether attendance at a preschool institution was a determinan to the development of petty motorism in children. The results obtained on a sample of 141 children do not confirm the assumption that the length of attendance at the preschool institution influences the indicators of fine motoring of children be fore enrollment in school. The variance an alysis showed that the difference sbetween groups and with ingroups were random because the F-test values $F=$ 0.708 with 2 degrees of freedom between groups and 138 degrees of freedom within groups and $p=0.494$ for the edge ornament and $F$ $=1.050$ with 2 degrees of freedom between groups and 138 degrees off reedom within groups and $p=0.353$ for a special test are not statistically significant. From the presented results, the iranalyzesand discussions, the basic conclusiono fthe research was drawn out, which states that the attendance of preschool in stitutions for one, two, three and more years does not influence the development of petty motoring in children. The obtained finding implies that the tests, the edge ornament and the special test, were 
Journal Plus Education, ISSN: 1842-077X, E-ISSN (online) 2068-1151 Vol XIX (2018), No. 1. pp. 55-65

quite difficult for children from the sample, which is explained primarily by the maturation of the structure, but alsoby specific learning and exercise that would contribute to the child's overall development.

Keywords: small engineers; preschool; children; graph omotors kills; visual perception;

\section{Introduction}

Bearing in mind that the family, most often, is not able to provide all the necessary conditions that would positively affect all aspects of development, institutional preschool education and upbringing appear as a supplement to family education, and in exceptional cases as a replacement for the family. Pre-school education enables the child to participate actively in the community of children who are similar to themselves in conditions that are adapted to the child, his possibilities, interests and development needs.

"The basic goal of staying children in preschool institutions is the overall development of every child's potential and progress in each of ist aspects, with the expansion andq ualitative improvement of those developmental ranges that the child has already won. It is an effort to forman emotional personality, aware of itself and ist potentials, ist social and natural environment, which is open, communicative, constructive and creative, satisfied with fulfillment of optimism in relation to itself, other people and life in general, which is governed by human values and aspirations, in which physical, intellectual, emotional and social characteristics, nurtured authenticneeds, developed personal characterlines, as well as individual preferences and abilities are balanced. Although a child has all the preconditions for developing a mature human person, spontaneous reporting of his mental and physical potential is not sufficient for them to developin to lasting personality traits. Therefore, in addition to thefamily, appropriate environment for children's development and learning, the intentional effects of pre-school institutions are necessary in order to achieve educational goals by encouraging, stimulating, developing and enriching children's natural potentials with in the physical, socio-emotional, spiritual, cognitive developmentand fostering child expression. These goals are realized through a system of activities that contribute to there alization of certain as pects of child development and personality as a whole, as ist trives to acquire experiences and knowledge, and they are realized with theneeds and possibilities of each individual child "(Kamenov, 1997, 48-9).

According to Article 22 oftheLaw on PreschoolEducation, preparatory preschool program is part of the regular program of the preschool institution 
in full-time or half-day duration, which is realized with the children in they ear be foregoing to school. Preparatory preschool program for children who are not included in the regular program of the preschool institution, is organized in pre-school institution, exceptionally in school, in accordance with the Law and the statute of the preschool institution or school. Exceptionally, a pre-school curriculum for children in the family can be organized for a shorter duration. More detailed conditions for the preparation of a pre-school program are prescribed by the Minister (page 7).

Children aged three to five and a half years old, as well as children attending pre-school programs (preparing for school), can be brought up and educated on the basis of the applicable law in Serbia using two models (A and $\mathrm{B}$ model). Model A gravitates an open system of upbringing and action development of programs depending on the interest of children, while model $\mathrm{B}$ has characteristics of cognitive - development program and elaborated educational goals, teacher tasks and types of activities among which the educator can choose and develop them depending on needs, possibilities and interest of children.

Pedagogical functions related to the activity of preschool education are only one of the domains of the activities of preschool institutions which, in addition to educational, have also a social and preventive-health function. One of the general tasks of preschools is that, by creating conditions for the development of a set of skills needed child later in life, contribute to physical maturity and readiness of children for school in terms of higher levels of general physical development, the development of motor skills and endurance to create, healthy and strong body of the child ready for the efforts that require the attendance of classes.In order to achieve as optimal a level of physical readiness, training should be done indirectly in the entire activity of the preschool institution, and directly by exercising all the contents that achieve the goals and tasks of physical, perceptual and health-hygienic activities.

\section{Indicators of petty (fine) motorism}

An important determinant of the physical maturity of children for going to school is the readiness, that is, the degree of development of the motor analyzer and the ability for fine motor coordination. This component of physical maturity is of great importance for writing, drawing, or for the child's success at school. Writing is an extremely complex psychophysiological skill based on the performance of fine-coordinated graphic movements. Graphic movements that make the motoric writing act belong to a class of voluntary motor skills.

The organization of psychomotorics of the upper extremities is in direct relation with the development of the psychosocial life of the 
personality as a whole. It arouses the basic schemes of the thought process and participates in the manifestation of creative needs, both of the child and of the adult in all those domains that characterize the social field and social life from its early beginnings. The upper extremities fit their activities with speech, intelligence, thinking and feelings, making one integral, which is the basic feature of psychosocial development and psychosocial life (Čordić, Bojanin, 1992, 71).

Research shows that the branch of children's hands of six and seven years old generally has a cylinder shape, somewhat widespread at the ends, with a poorly expressed "waist". So a survey of 1280 children has shown that the hand of a six-year-old child is morphologically sufficiently prepared for work that must be performed at school (Antropova i Koljcova, 1986, 154). When analyzing the motorism, the muscle tone mature at the latest and develops in parallel with the needs of increasingly finer activities in the manipulative field. The final phase of differentiation, which means that the maturity of the finger motorism will be mastering the graphomotor activities and the act of writing (Cordić, Bojanin, 1992, 72).

While the process of differentiation of the lower extremity tones is performed for 30 months of the child's life, so far the differentiation of the tones and the appearance of clean movements on the extremities of the upper extremities (fingers and palms of the hand) occurs only around the age of seven years. This allows the impulse for movement placed in certain muscle groups there, to arrive, without discharging into the adjacent areas. Thus, it is possible, according to needs, to perform completely precise manipulative activities. Thus, it is possible, according to needs, to perform completely precise manipulative activities. Further refinement of the movement, as well as the development of the structures involved in the movement, will certainly depend on the training and preservation of the anatomical and functional integrity of the nervous muscular circuits. This is the time when you lose the last side movements at rehearsals maturity assessment of muscle tone (Bojanin, 1979, 22). Other studies show that the hand of a six-year-old child, in most cases, is not capable of performing subtle, specialized movements necessary for writing (Marshall, 1983, 82) by its morphofficial possibilities.

At the age of children from six to seven years, "the graphomotor level appears as a kind of test or checking the organization of the psycho-motor circuit. This level, by special training, which means a special level of requirements, makes the children capable of completely specific activities" (Bojanin, 1979, 52).

Most of the manipulative activities involve vision as the basic control of the movement, especially until movement is automated. The connection between muscles of the eyes, fixation and graphomotor movements is established from the first attempts to hold chalk, crayons and pens.If this 
preparation is longer and more diverse, and the children deftly handle these instruments, so far to develop more precise, faster, more coordinated, more reliable hand movements directed by eye movements. In order for the child to achieve graphomotor and oculomotor coordination, it must go through three phases. During the first phase, it tries to get rid of the sharp, unspecified and disobedient movements of the hand. A child doodles, creates curly lines of various lengths, thicknesses, and directions. This is an elementary phase in which the oculomotor and graphomotor activity develop independently of one another.In the second phase at the level of brain function, transfers are established, so that the oculomotor and graphomotor action start to work together. This means that the hand comes under the control of vision. The muscular sence of pressure and kinesthetic for the movement are proprioceptively regulated. The hand achieves skill, but it is still under the control of a visual leader. The third phase, the highest one, is characterized by automated graphomotor movements. Oculomotor and graphomotor coordination are the condition for reaching this highest level.

The willingly, controlled hand movements as a precondition for writing letters or numbers, are developed by careful coordinated establishment of connections between the graphomotor muscular activity (Vladisavljević, interpretation, 1991, 97-8).It is important to note that "the practical and motor organization of the fine motorism is inherited function at which the speed of maturation is certainly influenced by many central factors that can be brought to virtuosity or impediment to degradation by practice" (Vladisavljević, 1991, 56). Most authors as indicators of psychomotor readiness for the adoption of graphomotor learning (fine motorism) state the level of development of coordination of movement, development of thinking (ability to generalize), visual and auditory observation, motor memory (memory of movement), attention, drawing skills and learning skills ( Batoev and Zankov: 1993, 8). The section of school pedagogues in Belgrade, in the course of examining the pre-knowledge of children enrolling in the first grade of primary school, in addition to other tests, applies the test called "marginal ornament" by Professor Friedrich Troy. This test examines graphomotor skills and visual perception.In addition, the understanding of tasks, the skill of their performance, independence in work, accuracy and ability to focus attention are followed. It has been shown that children with specific difficulties in visual perception and graphomotor disorders can be detected by it (Vladisavljević, 1991, 129).In addition to this test, the research uses a special test for the assessment of fine motor-coordination of the movement of compliance, autonomy in work, skill and accuracy. 


\section{Method}

Problem of research related to the analysis of scientific data on the basis of which it can be determined whether and how attending preschools affect the development of graphomotor skills and visual perception in children.In other words, it was necessary to use the experimental method to determine whether attending preschools for one, two, three or more years affects the indicators of petty motoring for children entering the first grade of Elementary School.

The subject of research is the relationship between attending preschools for one, two, three and more years and indicators of the petty motorism of children entering the first grade of Elementary School.

The aim of the research was to gather scientific data on the basis of which it can be determined whether and how much attending preschools affects the development of petty motor skills in children going to school.

Concretization and operationalization of the goals of research led to the following research tasks:

- Collect data on the length of attendance at a pre-school institution that is presumed to affect the development of petty motor skills in children attending school.

- Collect data by testing fine motor skills in children.

- Collected data by statistical procedures lead to mutual relations.

The study of preschool attendance as a determinate development indicators of fine motor skills should enable: determining the correlation between the examined parameterswith the length of preschool attendance expressed in years;comparing the results obtained with the findings of other researchers who have been questioning the phenomenapreviously examined under some other tasks and in other populations.

It is planned to calculate the connection between the indicators of petty motorism of children before enrollment in school and the length of attendance at the preschool institution.

Based on the defined subject of this work, taking into account the need and significance of the research, a hypothesis was put in place. It is assumed thatthere is a correlation between the indicators of petty motorism in children and the length of attendance at the preschool institution.

The problems of this research, in addition to theoretical analysis, views, perceptions and results of previous research from other relevant papers, dictated the need for the application of the descriptive method in order to describe the actual phenomena, the interpretation of the obtained results and the conclusions.In order to determine cause-effect relationships using the ex post-facto procedure, a causal method was used. The statistical 
procedure was used to determine the size of the phenomena being investigated and their relationships.

From the kinesiological research techniques in the work were applied: techniques of petty motor skills evaluation - fine (petty) motor tests; study of the pedagogical and psychological documents.

In accordance with research methods and techniques, appropriate instruments have been used. At the stage of collecting data on the length of attending at preschools, a questionnaire was used and pedagogicalpsychological documentation was studied.Fine motor testing was performed by pedagogues and psychologists using the Marginal Ornament and the Special Test. These tests are taken (Annex 1).

The population from which the sample was extracted for this study were children (141 children) before entering the first grade of primary school. The research included four preschool groups of children from two preschool institutions "Heroj Miša" and "Djordje Krstic" in Belgrade. The sample included approximately the same number of boys and girls. All the children in the sample attended preschool. A year was attended by 67 children, two years by 28 children and three or more years by 46 children.

Data obtained from the survey were processed by computer. Appropriate statistical techniques were applied in data processing. From descriptive statistical parameters for each variable, the arithmetic mean, standard deviation, minimum and maximum result, and frequency distribution were calculated.

The asymmetry of the curve of the results distribution relative to normal distribution was determined on the basis of the degree of curvature of the kurtosis and the degree of skewness of the skew. By determining the significance of the differences, considering the nature of the variables taken by the method of research, a $(\bullet 2)$ chi-square test was calculated. Due to the simultaneous examination of the equality of arithmetic meanings of several sets, a statistical method-analysis of variance was used. The statistical significance of the differences in the arithmetic mean of the corresponding variables between the two variances was determined using the F-test, and the statistical significance of the differences between the arithmetic meanings within the groups using the Tirky test.

The results of this study are presented in tables. Complete statistical data processing was done on the RS-computer using the statistical program SPSS.

\section{Results of research and discussion}

Fine (petty) motorism in children enrolling the first grade of elementary school were studied on the basis of the Marginal Ornament and the Special 
Test, and basic indicators of the development of fine motor skills were obtained.

Table 1.DescriptivestatisticalindicatorsfortheMarginal Ornament

\begin{tabular}{ccccccc}
\hline $\begin{array}{c}\text { Numbe } \\
\text { rof } \\
\begin{array}{c}\text { respon } \\
\text { dents }\end{array}\end{array}$ & $\mathrm{M}$ & $\delta$ & $\mathrm{SK}$ & $\mathrm{KU}$ & Minimum & Maximum \\
\hline 141 & 2,30 & 0,57 & $-1,28$ & 1,622 & 0,20 & 3,00 \\
\hline
\end{tabular}

Table2. DescriptivestatisticalindicatorsfortheSpecial Test

\begin{tabular}{ccccccc}
\hline $\begin{array}{c}\text { Number } \\
\text { of } \\
\begin{array}{c}\text { respondent } \\
\mathrm{s}\end{array}\end{array}$ & $\mathrm{M}$ & $\delta$ & $\mathrm{SK}$ & $\mathrm{KU}$ & Minimum & Maximum \\
\hline 141 & 5,92 & 2,71 & $-0,11$ & $-0,425$ & 0,00 & 12,00 \\
\hline
\end{tabular}

Both tests were done by all the children of the sample. Results of descriptive indicators of fine motor skills in peripheral ornament showed that the range of results expressed in points is from 0.20 to 3 points. The arithmetic mean is 2.30 points, the standard deviation is 0.57 points. Results of skewness $\mathrm{SK}=-1.28$ and kurtosis $\mathrm{KU}=1.622$ indicate that the frequency distribution of the normal curve is negatively skewed and leptokurtic.

The results of descriptiveindicators of fine motorism for the Special Test have shown that the range of results, expressed in points, ranges from 0 to 12 . The arithmetic mean is 5.92 points, the standard deviation is 2.71 points. The dimensions of the deviations from the normal distribution of skewness $\mathrm{SK}=-0.11$ and kurtosis $\mathrm{KU}=-0.425$ indicate a deviation of the obtained values and we conclude that the distribution is positively skewed and platykurtic in relation to the normal curve.

In order to have better examination and easier interpretation, as well as later discussions and conclusions, class interval groups were defined, three groups for each of the tested fine motor parameters. The criteria for this division is the arithmetic mean taken - one standard deviation of the parameters examined, the highest and the lowest result.

The first group-category includes children whose study values are below the average. The second category-group includes children whose average values are examined. The third group-category includes children whose values are above the average. 
Journal Plus Education, ISSN: 1842-077X, E-ISSN (online) 2068-1151 Vol XIX (2018), No. 1. pp. 55-65

Table 3.

Categoriesofchildrenaccording to theparameterstested

\begin{tabular}{|c|c|c|c|c|c|c|c|c|c|}
\hline & $\begin{array}{l}\text { Averag } \\
\mathrm{e} \\
\end{array}$ & $\begin{array}{l}\mathrm{N} \\
\mathrm{o} . \\
\end{array}$ & $\%$ & \begin{tabular}{|l} 
Belo \\
waver \\
age \\
\end{tabular} & $\begin{array}{l}\mathrm{N} \\
\mathrm{O} \\
\end{array}$ & $\%$ & $\begin{array}{c}\text { Above } \\
\text { average }\end{array}$ & $\begin{array}{l}\mathrm{N} \\
\underline{\mathrm{o}} \\
\end{array}$ & $\%$ \\
\hline & & & & & & & & & \\
\hline $\begin{array}{l}\text { Marginal } \\
\text { Ornament }\end{array}$ & $\begin{array}{l}1,73- \\
2,85 \\
\end{array}$ & 0 & $\begin{array}{c}76, \\
6 \\
\end{array}$ & $\underline{0,20-1,72}$ & $\begin{array}{l}2 \\
1 \\
\end{array}$ & $\begin{array}{c}14, \\
9 \\
\end{array}$ & $\begin{array}{l}2,86- \\
3,00\end{array}$ & $\begin{array}{l}1 \\
2\end{array}$ & \\
\hline Special Test & & $\begin{array}{l}8 \\
7\end{array}$ & 61,7 & $\begin{array}{c}0,00- \\
3,20\end{array}$ & $\begin{array}{l}2 \\
6\end{array}$ & $\begin{array}{c}18, \\
4\end{array}$ & $\begin{array}{l}8,64- \\
12,00\end{array}$ & $\begin{array}{l}2 \\
0\end{array}$ & 19 \\
\hline
\end{tabular}

Evaluation level of development of fine motor skills in children entering the first grade of primary school, was carried out based on the analysis of numerical tests: the Marginal ornament and Special test, shows that the average value for Marginal ornament within the limits expected to have obtained the average value for a Special test below the expected levels, although both tests evaluated graphomotor skills and visual perception.

Based on the analysis of results, the results of the Special test of children compared to the Marginal ornament showed low values, although the deviation measures of skewness and kurtosis indicate that both tests are difficult for the children to be tested. The obtained average score for the Marginal ornament 2.3 points, a minimum value of 0.20 points and a maximum value of 3.0 points indicates that 108 children (76.6\%) achieved a score of 1.73 to 2.85 points,below this average is 21 children (14.9\%), and above the average is 12 children $(8.5 \%)$.

The average score for the special test of 5.92 points, the minimum value of 0 points and the maximum value of 12 points, show that 87 children $(61.7 \%)$ achieved a score of 3.21 to 8.63 points, which places children in the average group in our research, although every child mature for school should score at least 8 points, in terms of the development of graphomotor skills and visual perception. Under the average are 26 children (18.4\%) with a score of 0.0 to 3.2 points, and above the average are 28 children (19.9\%) with results of 8.64-12 points. Adhering to the norms, the examined children with the above-average result, would have average results. The reasons for such low results should certainly be found in the factors responsible for this phenomenon. Graphomotor movements that make up the motoric act of writing are determined by the maturation of structures and their functions. Reporting normal tonic tension in the muscles of the upper extremities occurs mostly around the age of 7, when the child is also capable of performing fine manipulative movements (see the development of fine motor skills from birth to school age in the introductory part of the paper). This explanation justifies the weight of both tests but does not justify the drastic 
difference in the results. We have to look for it in the environmental factors, that is, in learning and practicing. The fact is that children in the family and pre-school institutions draw more circle (ball), + (cross) and triangles (roofs) than horizontal lines written below each other which require a high level of precision in children. The reason is, perhaps, the fact that children did not understand the task or did not have enough built and developed speed of movement as well as orientation in time, and the test, in contrast to a marginal ornament, was due to the time.

Table4.Attendingpreschoolinstitutionsandindicatorsof fine motorism

\begin{tabular}{|c|c|c|c|c|c|c|c|}
\hline $\begin{array}{l}\text { Anthropo- } \\
\text { motor } \\
\text { parameters }\end{array}$ & $\begin{array}{l}\text {. Attending } \\
\text { preschooli } \\
\text { nstitutions } \\
\text { (year) }\end{array}$ & $\begin{array}{c}\text { No. of } \\
\text { examine } \\
\mathrm{d}\end{array}$ & M & $\delta$ & F-test & $\begin{array}{c}\text { Degree } \\
\text { of } \\
\text { freedom }\end{array}$ & $\begin{array}{l}\text { Significance } \\
\text { of differences }\end{array}$ \\
\hline Marginal & กne & 67 & 978 & 058 & 0.708 & 7 & 0.494 \\
\hline Ornament & $\begin{array}{l}\text { Twwn } \\
\text { Three }+\end{array}$ & $\begin{array}{l}38 \\
46\end{array}$ & 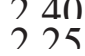 & $\begin{array}{l}\bigcap 47 \\
\cap 60\end{array}$ & & 138 & \\
\hline \multirow[b]{2}{*}{ Special Test } & กne & 67 & 567 & 359 & 1.050 & 2 & 0.353 \\
\hline & Three + & 46 & $\begin{array}{ll}6 & 51 \\
6 & 0\end{array}$ & 274 & & 138 & \\
\hline
\end{tabular}

The study results do not confirm the hypothesis according to which the length of preschool attendance affects indicators of fine motor skills of children before entering school. The variance analysis showed that the differences between groups and within groups were random because the Ftest values $F=0.708$ with 2 degrees of freedom between groups and 138 degrees of freedom within groups and $p=0.494$ for the marginal ornament and $F=1.050$ with 2 degrees of freedom between groups and 138 degrees of freedom within groups and $\mathrm{p}=0.353$ for a special test are not statistically significant.

When consolidating the impact of attending preschool institutions on the indicators of fine motorism, we did not establish a statistically significant relationship. So the hypothesis, that it is assumed there is a relationship between the fine motor skills of children and length of preschool attendance, was dropped.

\section{Conclusion}

In the theoretical part there was a lot of talk about the influence of organized institutional preschool education and upbringing on the general development of the child. One of the conclusions was that good preparation of one, two or more years, covering all aspects of the physical development of the child, should provide satisfactory results on which we can evaluate indicators of physical development of children for school. Our assumption that the preschool institution and the length of attendance expressed in 
years can be a factor that influences the indicators of fine motorism has not been confirmed. The obtained finding implies that the tests, the marginal ornament and the special test, were quite difficult for children in the sample, which is explained primarily by the maturation of the structure, but also by specific learning and exercise that would contribute to the child's overall development.

\section{References:}

Антропова, М. В., Кољцова, M. M. (1986). Психофизиолошказрелостдеце. Београд: Завод за уџбенике и наставна средства.

Белинова, Л.,Јирова М. (1976). Какоприпремитидијете за школу.Сарајево: ООУР Завод за уџбенике и наставна средства.

Даница, Џ., Владимир, П.: (2016). Квантитативне и квалитативнекарактеристике.морфолошког и моторичкогпросторапредшколскедеце. Београд: Учитељски факултетДаница, Џ., Владимир, П.: (2016). Мониторинг физичког васпитана. Београд:Драслар партнер.

Дуран, М. (1976). Утицајједногодишњегодгојно-образовног рада у предшколској установи на зрелост за полазаку школу.Предшколскодете, 2, 173-179.

Ђорђевић, Б. (1968). Зрелостдетета за полазаку школу и проблемиобуке, Настава и васпитање, 3, 265-76.

Граовац, В. (1999). Параметрипсихофизиолошке зрелости релевантни за упис у школу, Зборник, Емпиријскаистраживања у психологији.

Хорват, Л. (1986). Предшколсковаспитање и интелектуалниразвој. Београд: Завод за уџбенике и наставна средства.

Каменов, Е. (1997). Припремамдете за школу. Нови Сад: Тампограф.

Каменов, Е.(1999). Предшколскапедагогија. Београд: Завод за уџбенике и наставна средства.

Лурија, А. Р.(1982). Основинеуропсихологије.Београд: Нолит.

Медвед, Р.(1964). Критериј за одређивање зрелости за школовање. Физичка култура, 7-8, 294-298.

Мужић, В.(1968). Методологијапедагошкогистраживања.Сарајево: Завод за издавањеуџбеника.

Проскура, Е. (1977). О психологическој готовности к школе первоклассника.Дошкољноеваспитание, 8, 34-38. 